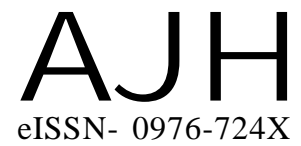

Received : 06.06.2015

Revised : 15.10 .2015

Accepted : 02.11.2015

Members of the Research Forum

Associated Authors:

${ }^{1}$ Department of Horticulture, College of Agriculture, Junagadh

Agricultural University, JUNAGADH (GUJARAT) INDIA

Author for correspondence :

D.K. VARU

Department of Horticulture, College

of Agriculture, Junagadh

Agricultural University, JUNAGADH

(GUJARAT) INDIA

Email : dkvaru@yahoo.com
THEASIAN JOURNALOF HORTICULTURE

Volume 10 | Issue 2 | December, 2015 | 187-193

Visit us -www.researchjournal.co.in

RESEARCH PAPER

DOI : 10.15740/HAS/TAJH/10.2/187-193

\title{
Effect of pre-harvest spray of chemicals on shelf- life and quality of mango cv. KESAR
}

\section{URVISH PATEL ${ }^{1}$, D.K. VARU AND JAMSU CHAUDHARI ${ }^{1}$}

ABSTRACT : A trial was conducted to study the effect of pre-harvest spray of chemicals on shelf-life and quality of mango cv. KESHAR. The experiment involved pre-harvest spray of nutrients combined with chemicals and plant growth regulators. The treatments included $\mathrm{GA}_{3}$ $25 \mathrm{ppm}+\mathrm{KNO}_{3} 2$ per cent $\left(\mathrm{T}_{1}\right), \mathrm{GA}_{3} 25 \mathrm{ppm}+\mathrm{ZnSO}_{4} 0.05$ per cent $\left(\mathrm{T}_{2}\right), \mathrm{GA}_{3} 25 \mathrm{ppm}+$ borex 1 per cent $\left(\mathrm{T}_{3}\right), \mathrm{GA}_{3} 25 \mathrm{ppm}+\mathrm{CaCl}_{2} 2$ per cent $\left(\mathrm{T}_{4}\right), 2,4-\mathrm{D} 20 \mathrm{ppm}+\mathrm{KNO}_{3} 2$ per cent $\left(\mathrm{T}_{5}\right), 2,4-\mathrm{D} 20 \mathrm{ppm}$ $+\mathrm{ZnSO}_{4} 0.05$ per cent $\left(\mathrm{T}_{6}\right), 2,4-\mathrm{D} 20 \mathrm{ppm}+$ borex 1 per cent $\left(\mathrm{T}_{7}\right)$ and $2,4-\mathrm{D} 20 \mathrm{ppm}+\mathrm{CaCl}_{2} 2$ per cent $\left(\mathrm{T}_{8}\right)$. The results obtained indicated that the tree sprayed with 2, 4-D $20 \mathrm{ppm}+\mathrm{ZnSO}_{4} 0.05$ per cent showed good results in fruit yield and yield attributing characters as well as shelf-life of mango. Whereas physical parameters like highest marketable fruit, minimum spoiled friut, minimum riped fruit as well as lowest days of ripening were recored in pre harvest spray of $\mathrm{GA}_{3} 25 \mathrm{ppm}+$ borex 1 per cent. The quality parameters like TSS, acidity, ascorbic acid, vitamin'A', colour, flavour, texture, taste and overall acceptability etc. were performed better in pre harvest spray of $\mathrm{GA}_{3} 25 \mathrm{ppm}+\mathrm{ZnSO}_{4} 0.05$ per cent $\left(\mathrm{T}_{2}\right)$ and $\mathrm{GA}_{3} 25 \mathrm{ppm}+\mathrm{CaCl}_{2} 2$ per cent $\left(\mathrm{T}_{4}\right)$.

KEY WORDS : Mango, $\mathrm{GA}_{3}, 2,4-\mathrm{D}, \mathrm{KNO}_{3}, \mathrm{ZnSO}_{4}$, Borex, $\mathrm{CaCl}_{2}$

HOW TO CITE THIS ARTICLE : Patel, Urvish, Varu, D.K. and Chaudhari, Jamsu (2015). Effect of preharvest spray of chemicals on shelf-life and quality of mango cv. KESAR. Asian J. Hort., 10(2) : 187-193. 